Institute of Physics (a joint report with the Mathematical Association; Math. Gaz., 80, pp. 37-38, 1996). As the Association's President in 1969 she endorsed her continued belief '... that the Mathematical Association can play a vital part in the progress of mathematical teaching at all levels.' (M.A. Newsletter 15, December 1969). In retirement Bertha maintained an interest in the work of the Association, but was saddened by the reduced participation of university mathematicians in its work.

Bertha's main contribution to mathematical education was in her role as Director of Studies in Mathematics at Girton and as a consequence her influence has spread worldwide. In recognition of this work she was awarded honorary degrees by the University of Saskatchewan in 1995 and the Open University in 1996. Over 30 years Bertha was involved in the selection, advising and teaching of women mathematicians at Girton, where she was able to communicate her love of mathematics and in particular mathematical physics to others. The discussion of mathematical problems formed the main part of her supervisions but Bertha attached great importance to the precise and correct use of English in the expression of mathematics. Initially Bertha may have seemed formidable to her young students, but she had the kindest heart and frequently on a Sunday evening there was 'open house', with home made goodies to eat, at the Jeffreys home on the Huntingdon Road. Bertha maintained a great interest in the welfare and careers of her former students and they, with their children and even grandchildren, became her extended family. Throughout her long retirement there were numerous visitors at her home and on the occasion of her 90th birthday about $\mathbf{1 4 0}$ former students attended a birthday lunch at Girton College. This was a fitting tribute to a well loved and respected teacher, friend and colleague.

I would like to thank both Dr Ruth Williams and Dr Michael Price for information used in writing this obituary.

MARY WALMSLEY

20 Linwal Avenue, Houghton on the Hill, Leicester LE7 9HD

\title{
David George Crighton 1942 - 2000
}

As many readers will know, David Crighton died in April after a lengthy illness. Latterly, he was Professor of Applied Mathematics in the University of Cambridge, and Master of Jesus College. He was a member of the Association and a former president of the Yorkshire Branch. It is impossible to do justice to his huge range of mathematical activities in this short piece. My own small contact with him was through our involvement with the Pop Maths Roadshow.

The Memorial Service was held in in Great St Mary's, Cambridge, on Saturday 3 June and I was pleased to attend and represent the Association.

BILL RICHARDSON 